\title{
Evaluation of Rubber Tree Clones Under Different Tapping Systems in Northwestern Paraná State, Brazil.
}

\author{
Jomar da Paes Pereira ${ }^{1}$, Alex Carneiro Leal ${ }^{1 *}$, Andre Luiz Medeiros $\operatorname{Ramos}^{1}$ \\ ${ }^{1}$ Instituto Agronômico do Paraná - Londrina, Paraná, Brasil
}

\begin{abstract}
This study evaluates the potential of rubber tree clones (Hevea spp.) under four tapping systems for the Northwestern region of the State of Parana with the objective of enhance genetic diversification and increase natural rubber production in this new and promising region for rubber tree cultivation by selecting the better combination of clone and tapping system. The experiment was installed at Guanabara Farm, municipality of Paranapoema, Paraná State, in a split-plot randomized complete blocks experimental design with three replications. In the plots 12 clones were tested, namely RRIM 600 (control), IRCA 18, IRCA 111, IRCA 130, PB 235, PB 252, PB 260, PB 330, IAC 15, IAC 35, IAC 41 and RO 38. The subplot treatments consisted of four tapping systems: 1) $1 / 2 S$ $d / 4$ ET 2.5\%, 2) $1 / 2 S d / 4,3) 1 / 2 S d / 7$ ET $2.5 \%$ and 4) $1 / 2 S d / 7$. Dry rubber production was evaluated over a period of two years. Due to the higher productivity the clones IRCA 130, IRCA 111, IRCA 18, IAC 35, IAC 41, IAC 15, PB 260 and $P B 235$ are suggested to be planted at a proportion of 5\% to 10\% of the total area in commercial plantings for more detailed evaluation. Because of their significantly lower productivity, the clones $P B 330, P B 252$ and RO 38 should not be recommended, as well as the tapping system $S \mathrm{~d} / 7 \mathrm{l} / 2$ without stimulation.
\end{abstract}

Keywords: Hevea brasiliensis, natural rubber, yield.

\footnotetext{
*Author for correspondence: alex@iapar.br
} 


\section{INTRODUCTION}

The rubber tree, Hevea brasiliensis (Willd. ex. Adr. Jus.) Muell. Arg., is the principal source of natural rubber, a strategic raw material for major industrial sectors such as the automotive. Currently natural rubber production is concentrated on Southeast Asia and Brazil participates in the world market as an importer. The modest production of natural rubber in Brazil (about 1\% of total world production and 30\% of national consumption) is concentrated in the State of São Paulo, which accounts for more than $60 \%$ of the total amount produced in the country ${ }^{15,16}$.

Agroclimatological zoning for rubber cultivation demonstrates the enormous potential in non-traditional Brazilian States, such as São Paulo, Pernambuco, Minas Gerais, Goiás, Mato Grosso, Mato Grosso do Sul, Maranhão, Espírito Santo, Rio de Janeiro and Paraná. In some specific regions of these States the seasonal variation of temperature and/or humidity prevents the South American Leaf Blight (SALB) caused by the fungus Microcyclus ulei P. Henn. This disease severely limits the rubber production and these regions are being considered SALB free areas (escape areas) ${ }^{13}$. According to Vasquez Cortez ${ }^{22}$, the availability of SALB free areas suitable for growing rubber trees in Brazil is greater than the total area cultivated worldwide with the species.

One of the most important characters in the selection of Hevea cultivars is the latex yield. However, the expression of the potential yield of the cultivar is influenced by several intrinsic factors, such as: vigor, bark thickness, resistance to wind and diseases, as well as management practices regarding tapping systems, chemical stimulation, planting density and plant nutrition ${ }^{12}$.

Soil and climatic conditions as water, temperature and rainfall deficits affect the components of growth and production, contributing significantly with a great variability in the behavior of the different cultivars and explain in large part the variations in performance of clones. Plant varieties that are considered productive in certain areas may behave differently in other areas of the same or other regions ${ }^{8,18}$.

In order to ensure technical, social and economic competitiveness for the productive chain of natural rubber in different ecological areas, the introduction and evaluation of new cultivars is of paramount importance ${ }^{9,16}$.

The Northwest region of Paraná State comprises an area of 3.2 million ha with humid subtropical climate and soils with low clay content. The region provides favorable conditions for the cultivation of rubber trees, but currently have only about 1000 hectares with rubber trees and few alternative options of productive clones adapted to the region ${ }^{4,15}$.

The purpose of this work was to evaluate some productive clones successfully grown in other producing regions and to select the better combination of clone and tapping system with the objective of expanding the options of suitable clones for planting by farmers in Northwestern Paraná and increased rubber cultivation competitiveness at Paraná State.

\section{MATERIAL AND METHODS}

The experiment was installed in May 1998 at the Guanabara Farm in the municipality of Paranapoema, northwestern region of Paraná State $\left(22^{\circ} 43^{\prime} \mathrm{S}\right.$ and $57^{\circ} 07^{\prime} \mathrm{W}$ at 400 $\mathrm{m}$ above sea level). The climate is Cfa according to Köppen classification: subtropical, with no dry season and temperature of the hottest month above $22^{\circ} \mathrm{C}$ with annual rainfall is around $1500 \mathrm{~mm}^{11}$. 
The soil, classified as Argissolo Vermelho Amarelo, is sandy (85\% and $15 \%$ clay), acid ( $\mathrm{pH}$ in $\mathrm{CaCl}_{2}$ around 4.0), with average carbon content between $0.5 \%$ and $1.0 \%$ and flat topography.

The experimental design was laid out in a factorial split-plot arrangement based on a randomized complete block design with three replications. The plots were composed of 18 plants and. the spacing was of $8.0 \mathrm{~m} \mathrm{x} 2.5 \mathrm{~m}$ (500 plants per hectare). Twelve clones were tested in the plots, eight of them currently used in commercial plantations in major natural rubber producing countries: RRIM 600 (control), IRCA 18, IRCA 111, IRCA 130, PB 236, PB 252, PB 260, PB 330 and four Brazilian clones: IAC 15, IAC 35, IAC 41, RO 38 (table 1).

Table 1 - Parental and origin of 12 rubber tree clones established in large-scale experiment in Guanabara Farm, Paranapoema-PR

\begin{tabular}{lll}
\hline CLONES & PARENTAL & ORIGIN \\
\hline IRCA 130 & PB 5/51 X IR 22 & Ivory Coast \\
PB 330 & PB 5/51 (PB 24 x PB 56) x PB 32/36 (PB 49 x PB 186) & Malaysia \\
IAC 35 & FX 25 (F 361 x AVROS 49) x RRIM 600 (Tjir 1 x PB 86) & Brazil \\
PB 235 & PB 5/51 (PB 24 x PB 56) x PB S/78 (PB 49 x PB 25) & Malaysia \\
IAC 15 & RRIM 507 (Pil B84 x Pil A 44) x RRIM 600 (Tjir 1 x PB 86) & Brazil \\
IRCA 111 & RRIM 507 (Pil B 50 x Pil B 84) x Fx 25 (F 361 x AVROS 49) & Ivory Coast \\
IAC 41 & RRIM 608 (AVROS 33 x Tjir 1) x AVROS 1279 (AVROS 256 x AVROS 374) & Brazil \\
PB 252 & PB 86 x PB 32/36 (PB 49 x PB 186) & Malaysia \\
RO 38 & Primary clone & Brazil \\
IRCA 18 & PB 86 x B 1717 & Ivory Coast \\
PB 260 & PB 5/51 (PB 56 x PB 24) x PB 49 & Malaysia \\
RRIM 600 & Tjir 1 x PB 86 & Malaysia \\
\hline
\end{tabular}

Four tapping systems were tested in the subplots, namely:

1) d/4 with: $1 / 2 \mathrm{~S} \mathrm{~d} / 46 \mathrm{~d} / 7,11 \mathrm{~m} / \mathrm{y}$, ET $2.5 \% \mathrm{~Pa}$ La 8/y (tapping in half spiral (1/2 S), at intervals of four days $(\mathrm{d} / 4)$, with rest on Sundays (6d/7), tapping 11 months a year (11 $\mathrm{m} / \mathrm{y}$ ), stimulated with ethephon at 2.5\% (ET 2.5\%) applied in the tapping panel (Pa) on the latex flowing channel with coagulated latex (La), eight times a year (8/y);

2) d/4 without: $1 / 2 \mathrm{~S} \mathrm{~d} / 46 \mathrm{~d} / 7,11 \mathrm{~m} / \mathrm{y}, \mathrm{Pa} \mathrm{La}$ 8/y (tapping in half spiral $(1 / 2 \mathrm{~S})$, at intervals of four days $(\mathrm{d} / 4)$, with rest on Sundays $(6 \mathrm{~d} / 7)$, tapping 11 months a year (11 $\mathrm{m} / \mathrm{y})$;

3) d/7 with: $1 / 2 \mathrm{~S} \mathrm{~d} / 76 \mathrm{~d} / 7,11 \mathrm{~m} / \mathrm{y}$, ET $2.5 \% \mathrm{~Pa} \mathrm{La} 8 / \mathrm{y}$ (tapping in half spiral ( $1 / 2 \mathrm{~S}$ ), at intervals of four seven days $(\mathrm{d} / 7)$, with rest on Sundays $(6 \mathrm{~d} / 7)$, tapping 11 months a year $(11 \mathrm{~m} / \mathrm{y})$, stimulated with ethephon at $2.5 \%$ (ET 2.5\%) applied in the tapping panel $(\mathrm{Pa})$ on the channel with coagulated latex $(\mathrm{La})$, eight times a year $(8 / \mathrm{y})$;

4) $\mathrm{d} / 7$ without: $1 / 2 \mathrm{~S} \mathrm{~d} / 76 \mathrm{~d} / 7,11 \mathrm{~m} / \mathrm{y}, \mathrm{Pa} \mathrm{La}$ 8/y (tapping in half spiral $(1 / 2 \mathrm{~S})$, at intervals of four seven days $(\mathrm{d} / 7)$, with rest on Sundays (6d/7), tapping 11 months a year $(11 \mathrm{~m} / \mathrm{y})$.

In the treatments with tapping frequency $\mathrm{d} / 4$ six plants were tested with stimulation and an equal number without stimulation, while in the treatments with frequency $\mathrm{d} / 7$ three plants were tested for each treatment.

The trees were prepared for tapping at the eighth year after planting and the collection of experimental data started four years later. The production of latex was obtained by weighing the latex naturally coagulated in the cups in the sub-plots every month. For each subplot a sample of the coagulated rubber was dried in oven at $45^{\circ} \mathrm{C}$ until constant weight to determine the humidity content and calculate the dry rubber 
production per tree per tapping. The annual dry rubber production per hectare was estimated considering 78 cuts per tree per year in the systems with $\mathrm{d} / 4$ tapping frequency and 52 cuts per tree per year in the $d / 7$ systems and a stand of 450 trees per hectare $^{6}$.

Statistical analysis of the data was performed using the Sisvar software ${ }^{7}$. The data were tested for normality and homogeneity of variances. The averages were grouped by Scott-Knott test for comparisons of treatments ${ }^{2}$.

\section{RESULTS AND DISCUSSION}

The analysis of variance of annual dry rubber production per hectare indicated highly significant differences between treatments in plots and subplots, i.e., there were differences between clones and between systems of tapping by the F-test with $1 \%$ probability. There was no effect of blocks and the interaction plot $\mathrm{x}$ subplot was not significant by the F-test with $5 \%$ of probability (table 2). However, the comparisons among main plot treatments within subplot treatments as well as among subplot within main plot treatments revealed significant $(\alpha=5 \%)$ and highly significant $(\alpha=1 \%)$ simple effects. Therefore, we decided, as suggested by Perecin and Cargnelutti Filho ${ }^{14}$, to apply a less rigorous level of significance for interpretation of the interaction "by experiment" and maintain the usual $\mathrm{p}=0.05$ level for effect "by comparisons" in order to visualize important information from the interactions.

Table 2 - Mean square ANOVA of dry rubber production $\left(\mathrm{kg} \cdot \mathrm{ha}^{-1} \cdot \mathrm{yr}^{-1}\right)$ of 12 clones under four tapping systems.

\begin{tabular}{lccc}
\hline Source of variation & DF & Mean square & $\operatorname{Pr}>\mathrm{Fc}$ \\
\hline Blocks & 2 & $66813.94^{\mathrm{ns}}$ & 0.5968 \\
Clones & 11 & $1533740.88^{* *}$ & 0.0000 \\
Residue (a) & 22 & 126442.32 & \\
Tapping systems & 3 & $472274.18^{* *}$ & 0.0000 \\
Clones x Tapping system & 33 & $59393.37^{\mathrm{ns}}$ & 0.3144 \\
Residue (b) & 72 & 52029.82 & \\
\hline Overall average: $1333.41 \mathrm{~kg} \cdot \mathrm{ha}^{-1} \cdot \mathrm{yr}^{-1}$ & & \\
$\mathrm{CV}_{1} \%(\mathrm{a})=26.67$ & & & \\
$\mathrm{CV}_{2} \%$ (b) $=17.11$ & & & \\
\hline${ }^{\text {ns }}$ Not significant. & & \\
\end{tabular}

The overall productivity average was $1333 \mathrm{~kg} \cdot \mathrm{ha}^{-1} \cdot \mathrm{yr}^{-1}$, value within the range expected for the culture in the early years of exploitation and the range of the coefficients of variation in the experiment were high and medium for the plot and subplot respectively ${ }^{17}$.

For the factor clone, the RO 38 had the lowest productivity, indicating poor adaptability to the soil and climate conditions of the Northwest of Paraná, possibly because of greater water requirement. The clones PB 330 and PB 252 attained significantly lower productivities as compared to control (RRIM 600). The other clones were not different from the control, but nonetheless the IAC 41 and IAC 35 clones achieved, respectively, productivities $24 \%$ and $19 \%$ above the control (table 3). 
Rubber clones x tapping systems in Paraná

Table 3 - Dry rubber production $\left(\mathrm{kg} \cdot \mathrm{ha}^{-1} \cdot \mathrm{yr}^{-1}\right)$ of 12 rubber tree clones under four different tapping systems $*$

\begin{tabular}{lcc}
\hline Clone & Dry rubber production & $\%$ RRIM 600 \\
\hline IAC 35 & $1704 \mathrm{a}$ & 124 \\
IAC 41 & $1635 \mathrm{a}$ & 119 \\
IRCA 130 & $1570 \mathrm{a}$ & 114 \\
PB 235 & $1547 \mathrm{a}$ & 113 \\
IAC 15 & $1480 \mathrm{a}$ & 108 \\
IRCA 18 & $1479 \mathrm{a}$ & 108 \\
PB 260 & $1434 \mathrm{a}$ & 105 \\
IRCA 111 & $1372 \mathrm{a}$ & 100 \\
RRIM 600 & $1371 \mathrm{a}$ & 100 \\
PB 330 & $1022 \mathrm{~b}$ & 74 \\
PB 252 & $923 \mathrm{~b}$ & 67 \\
RO 38 & $464 \mathrm{c}$ & 34 \\
\hline
\end{tabular}

* Means followed by same letters do not differ by Scott-Knott test $(\alpha=0.05)$.

Significant difference was found between the factor tapping systems $1 / 2 \mathrm{~S} d / 7$ without stimulation and the other systems tested. Among the tapping systems the $1 / 2 \mathrm{~S}$ d/4 ET $2.5 \%$ attained the highest average, $1.453 \mathrm{~kg} \cdot \mathrm{ha}^{-1} \cdot \mathrm{yr}^{-1}$, similar to the systems $\mathrm{d} / 4$ without and $\mathrm{d} / 7$ with (table 4).

Table 4 - Dry rubber production $\left(\mathrm{kg} \cdot \mathrm{ha}^{-1} \cdot \mathrm{yr}^{-1}\right)$ of four different tapping systems in 12 rubber tree clones*

\begin{tabular}{lc}
\hline Tapping system & Production \\
\hline $\mathrm{d} / 4$ with $(1 / 2 \mathrm{~S} d / 4$ ET $2.5 \% 8 \mathrm{y})$ & $1453 \mathrm{a}$ \\
$\mathrm{d} / 4$ without $(1 / 2 \mathrm{~S} d / 4)$ & $1333 \mathrm{a}$ \\
$\mathrm{d} / 7$ with $(1 / 2 \mathrm{~S} d / 7$ ET $2.5 \% 8 \mathrm{y})$ & $1367 \mathrm{a}$ \\
$\mathrm{d} / 7$ without $(1 / 2 \mathrm{~S} d / 7)$ & $1179 \mathrm{~b}$ \\
\hline
\end{tabular}

* Means followed by same letters do not differ by Scott-Knott test $(\alpha=0.05)$.

The analysis of variance of the clones within each tapping system showed highly significant differences for all tapping systems (table 5).

Table 5 - Mean square ANOVA of clones within each tapping system (dry rubber productivity in $\mathrm{kg} \cdot \mathrm{ha}^{-1} \cdot \mathrm{yr}^{-1}$ ).

\begin{tabular}{lccc}
\hline Source of variation & DF & Mean square & $\mathrm{Pr}>\mathrm{Fc}$ \\
\hline Clones/d/4 with (1/2 S d/4 ET 2.5\% 8y) & 11 & $357003.90 * *$ & 0.0000 \\
Clones/d/4 without (1/2 S d/4) & 11 & $430506.79 * *$ & 0.0000 \\
Clones/d/7 with (1/2 S d/7 ET 2.5\% 8y) & 11 & $537060.04 * *$ & 0.0000 \\
Clones/d/7 without (1/2 S d/7) & 11 & $387350.27 * *$ & 0.0000 \\
Residue & 75 & $70632.95 * *$ & \\
${ }^{* *}$ Significant at 1\% probability. & & &
\end{tabular}

Tapping systems results within each clone were significantly different for the clones IAC 41, IRCA 130, PB 235, PB 330 and RRIM 600, however the Scott-Knott test did not confirm significant differences among tapping systems for the clone PB 330 (table $6)$. 
Table 6 - Mean square ANOVA of tapping system within each clone (productivity of dry rubber in $\mathrm{kg} \cdot \mathrm{ha}^{-1} \cdot \mathrm{yr}^{-1}$ ).

\begin{tabular}{lccc}
\hline Source of variation & DF & Mean square & Pr>Fc \\
\hline Tapping systems/IAC 15 & 3 & $19545.66^{\text {n.s. }}$ & 0.7703 \\
Tapping systems/IAC 35 & 3 & $34939.48^{\text {n.s. }}$ & 0.5711 \\
Tapping systems/IAC 41 & 3 & $22345.73^{* *}$ & 0.0076 \\
Tapping systems/IRCA 111 & 3 & $80624.46^{\text {n.s. }}$ & 0.2079 \\
Tapping systems/IRCA 130 & 3 & $145968.18^{*}$ & 0.0452 \\
Tapping systems/IRCA 18 & 3 & $25351.73^{\text {n.s. }}$ & 0.6914 \\
Tapping systems/PB 235 & 3 & $202530.42^{*}$ & 0.0121 \\
Tapping systems/PB 252 & 3 & $38471.69^{\text {n.s. }}$ & 0.5307 \\
Tapping systems/PB 260 & 3 & $17821.00^{\text {n.s. }}$ & 0.7942 \\
Tapping systems/PB 330 & 3 & $156434.77^{*}$ & 0.0354 \\
Tapping systems/RO 38 & 3 & $30883.01^{\text {n.s. }}$ & 0.6202 \\
Tapping systems/RRIM 600 & 3 & $149985.13^{*}$ & 0.0412 \\
Residue & 72 & 52029.82 & \\
\hline
\end{tabular}

n.s. Not significant. ${ }^{*}$ Significant at 5\% probability. ${ }^{* *}$ Significant at $1 \%$ probability.

Less intensive tapping systems such as $1 / 2 \mathrm{~S} d / 7$ are usually indicated for optimized labor management, as they allow the worker to tap more trees per working day and are suggested in situations when labor is a limiting factor or have high cost, besides offering the advantage of and increased productive life of the rubber plantation. The results of this experiment suggest that for less intensive tapping systems the clones that responded positively to stimulation with ethefon should be preferred, as the traditional RRIM 600 or PB 235 and IAC 41, given that these clones obtained significant lower yields in $\mathrm{d} / 7$ without stimulation.

Silva et al. ${ }^{20,21}$ obtained greater productivity and profitability with the clone RRIM 600 in São Paulo upland conditions applying the tapping system $1 / 2 \mathrm{~S} \mathrm{~d} / 3$ ET $2.5 \%$ and reported that the system $1 / 2 \mathrm{Sd} / 7$ ET $2.5 \%$ produced about $28 \%$ less. However, the productivity of this clone in the Northwest of Paraná was $10 \%$ higher in the system $1 / 2$ $\mathrm{S} \mathrm{d} / 7$ ET $2.5 \%$ as compared to the $1 / 2 \mathrm{~S} \mathrm{~d} / 4$ ET $2.5 \%$ and $40 \%$ more compared to the $1 / 2$ $\mathrm{S} \mathrm{d} / 4$ without stimulation (Table 7), so that the utilization of tapping system $1 / 2 \mathrm{~S} \mathrm{~d} / 7$ ET $2.5 \%$ can offer advantage in the conditions of Paraná State, with respect to production and optimization of manpower.

Even in the conditions of São Paulo plateau Silva et al. ${ }^{19}$ recorded that the system $1 / 2 \mathrm{~S}$ $\mathrm{d} / 2$ provided the greatest productivity of clone PB 235 and commented that this clone usually exhibit weak response to stimulation, but affirm that in the system $1 / 2 \mathrm{~S} \mathrm{~d} / 7 \mathrm{ET}$ $2.5 \%$ yield was superior to the $1 / 2 \mathrm{~S} d / 4$ ET $2.5 \%$ and recommend the system $1 / 2 \mathrm{~S} \mathrm{~d} / 7$ ET $2.5 \%$ due to absence of tapping panel dryness (TPD) disorder. Under the conditions of the Northwest of Paraná the clone PB 235 responded positively to stimulation in $\mathrm{d} / 7$ with a productivity of $1729 \mathrm{~kg} \cdot \mathrm{ha}^{-1} \cdot \mathrm{yr}^{-1}$, as well as the clone IRCA 111 that produced $1603 \mathrm{~kg} \cdot \mathrm{ha}^{-1} \cdot \mathrm{yr}^{-1}$ (table 7), both recommended by Alem et al. ${ }^{1}$ for small-scale plantations in the São Paulo Northwest plateau. 
Rubber clones x tapping systems in Paraná

Table 7 - Dry rubber production $\left(\mathrm{kg} \cdot \mathrm{ha}^{-1} \cdot \mathrm{yr}^{-1}\right)$ of 12 clones of rubber tree submitted to four tapping systems.*

\begin{tabular}{lcccc}
\hline Clones & d/4 with & d/4 without & d/7 with & d/7 without \\
\hline IRCA 130 & $1678 \mathrm{~A} \mathrm{a}$ & $1829 \mathrm{~A} \mathrm{a}$ & $1387 \mathrm{~B} \mathrm{a}$ & $1386 \mathrm{~B} \mathrm{a}$ \\
IAC 41 & $1811 \mathrm{~A} \mathrm{a}$ & $1729 \mathrm{~A} \mathrm{a}$ & $1771 \mathrm{~A} \mathrm{a}$ & $1229 \mathrm{~B} \mathrm{a}$ \\
IAC 35 & $1819 \mathrm{~A} \mathrm{a}$ & $1579 \mathrm{~A} \mathrm{a}$ & $1653 \mathrm{~A} \mathrm{a}$ & $1764 \mathrm{~A} \mathrm{a}$ \\
PB 235 & $1709 \mathrm{~A} \mathrm{a}$ & $1578 \mathrm{~A} \mathrm{a}$ & $1729 \mathrm{~A} \mathrm{a}$ & $1170 \mathrm{~B} \mathrm{a}$ \\
IAC 15 & $1527 \mathrm{~A} \mathrm{a}$ & $1564 \mathrm{~A} \mathrm{a}$ & $1442 \mathrm{~A} \mathrm{a}$ & $1386 \mathrm{~A} \mathrm{a}$ \\
IRCA 18 & $1562 \mathrm{~A} \mathrm{a}$ & $1433 \mathrm{~A} \mathrm{a}$ & $1551 \mathrm{~A} \mathrm{a}$ & $1372 \mathrm{~A} \mathrm{a}$ \\
PB 260 & $1528 \mathrm{~A} \mathrm{a}$ & $1355 \mathrm{~A} \mathrm{a}$ & $1463 \mathrm{~A} \mathrm{a}$ & $1390 \mathrm{~A} \mathrm{a}$ \\
IRCA 111 & $1368 \mathrm{~A} \mathrm{a}$ & $1257 \mathrm{~A} \mathrm{~b}$ & $1603 \mathrm{~A} \mathrm{a}$ & $1254 \mathrm{~A} \mathrm{a}$ \\
RRIM 600 & $1478 \mathrm{~A} \mathrm{a}$ & $1169 \mathrm{~B} \mathrm{~b}$ & $1636 \mathrm{~A} \mathrm{a}$ & $1205 \mathrm{~B} \mathrm{a}$ \\
PB 330 & $1311 \mathrm{~A} \mathrm{a}$ & $1056 \mathrm{~A} \mathrm{~b}$ & $959 \mathrm{~A} \mathrm{~b}$ & $762 \mathrm{~A} \mathrm{~b}$ \\
PB 252 & $1041 \mathrm{~A} \mathrm{~b}$ & $1000 \mathrm{~A} \mathrm{~b}$ & $824 \mathrm{~A} \mathrm{~b}$ & $828 \mathrm{~A} \mathrm{~b}$ \\
RO 38 & $610 \mathrm{~A} \mathrm{~b}$ & $455 \mathrm{~A} \mathrm{c}$ & $390 \mathrm{Ac}$ & $402 \mathrm{~A} \mathrm{~b}$ \\
\hline
\end{tabular}

* Means followed by same uppercase letter in the line and lowercase letter in the column do not differ by Scott-Knott test $(\alpha=0.05)$.

Silva et al ${ }^{19}$ observed high incidence of TPD disorder in PB 260 clone in $1 / 2 \mathrm{~S}$ system $\mathrm{d} / 3$ ET $2.5 \%$ and suggest, to avoid this problem, the system $1 \frac{1}{2} \mathrm{~S} \mathrm{~d} / 5$ ET $2.5 \%$ or $1 / 2 \mathrm{~S}$ d/7 ET 5\%. In the present study the PB 260 showed no difference among the tapping systems studied.

Corredato et al..$^{5}$ in a study in the Northwest of Paraná with clones PB 235, IAN 873, GT 1 and RRIM 600 subjected to tapping systems $1 / 2 \mathrm{~S} \mathrm{~d} / 3,1 / 2 \mathrm{~S} \mathrm{~d} / 4$ and $1 / 2 \mathrm{~S} d / 5$, all stimulated with $3 \%$ ethefon, reported that tapping frequency influenced the productivity of RRIM 600 and that PB 235 had its production reduced under $1 / 2 \mathrm{~S}$ d/4. These results agree with those obtained in this experiment for RRIM 600 that showed no difference between the tapping frequencies $\mathrm{d} / 4$ and $\mathrm{d} / 7$ when stimulated, but do not confirm the results obtained with the PB 235, whose production was not influenced by tapping frequency in systems with stimulation $(1 / 2 \mathrm{~S} \mathrm{~d} / 4$ ET $2.5 \%$ and $1 / 2 \mathrm{~S} d / 7$ ET $2.5 \%)$ (Table 7).

Most of the clones showed no differences in productivity in relation to tapping system. The Scott-Knott test pointed out differences in the performance of four clones due to tapping system. The productivity of the IRCA 130 clone was favored by the $1 / 2 \mathrm{~S} \mathrm{~d} / 4$ without stimulation, the IAC 41 and PB 235 were less productive in the system $1 / 2 \mathrm{~S}$ $\mathrm{d} / 7$ without stimulation and the RRIM 600 responded favorably to stimulation with ethefon under $\mathrm{d} / 4$ and $\mathrm{d} / 7$ (table 7 ).

The results indicate that, with the exception of RRIM 600, most of the clones tested showed no effects on production, from stimulation. However, stimulation can be recommended for the clones IAC 41, IRCA 111 and PB 235 when subjected to low tapping frequency $(\mathrm{d} / 7)$.

\section{CONCLUSIONS}

The results lead to the following conclusions, applicable to the Northwestern region of Paraná State conditions:

The clones IRCA 130, IRCA 111, IRCA 18, IAC 41, IAC 35, IAC 15, PB 260 and $\mathrm{PB} 235$ have potential for cultivation in commercial plantations.

The clones IRCA 130, IAC 35 and IAC 41 tapped on d/4 frequency exempt the use of stimulating agents. 
The stimulation with $2.5 \%$ ethefon can be advantageous for RRIM 600 as well as for PB 235, IRCA 111 and IAC 41 when tapped in $1 / 2 \mathrm{~S} d / 7$.

The tapping system $1 / 2 \mathrm{~S} d / 7$ without stimulation is not suitable for any of the clones tested.

\section{ACKNOWLEDGEMENTS}

The authors wish to thank the Companhia Melhoramentos Norte do Paraná - CMNP for support and staff support, without which it would not be possible to conduct this research. We also thank the technicians Paulo Rezende e João Gonçalves for their dedication and commitment to the data collection activities all along the duration of the experiment.

\section{REFERENCES}

1. Alem HM, Gouvêa LRL, Silva, GAP, Oliveira ALB, Gonçalves PS. Avaliação de clones de seringueira para a região noroeste do Estado de São Paulo. Rev. Ceres 2015; 62:430-437.

2. Borges LC, Ferreira DF. Poder e taxas de erro tipo 1 dos testes Scott-Knott, Tukey e Student-Newman-Keuls sob distribuições normal e não normal dos resíduos. Rev. Mat. Estat. 2003; 21:67-83.

3. Camargo AP. Possibilidades climáticas da cultura da seringueira em São Paulo. $2^{\mathrm{a}}$ ed. Campinas: Instituto Agronômico; 1963. 23p. (Boletim, 110).

4. Caramori PH, Gonçalves SL, Faria RT, Caviglione JH, Oliveira D, Galdino J, Pugsley I, Wrege MS, Borrozino E, Sonomura MGY, Giacomini CC. Zoneamento Agrícola do Estado do Paraná. Londrina: Iapar; 2003. 69p.

5. Corredato RA, Malavasi UC, Malavasi MM. Efeito da frequência da sangria em diferentes clones na produtividade de seringueira. Scientia Agraria Paranaensis, 2014; 13:318-322.

6. Embrapa. Centro Nacional de Pesquisa em Seringueira e Dendê. Melhoramento genético da seringueira. Manaus: Embrapa-CNPSD; 1989. 23p. (Embrapa-CNPSD. Documentos, 10).

7. Ferreira DF. Sisvar: a computer statistical analysis system. Ciênc. agrotec. 2011; 35:10391042.

8. Gonçalves PS, Bortoletto N; Ortolani AA, Belletti GO, Santos WR. Desempenho de novos clones de seringueira.III. Seleções promissoras para a região de Votuporanga, Estado de São Paulo. Pesq. agropec. bras. 1999; 34:971-980.

9. Gonçalves PS; Aguiar ATE; Gouvêa LRL. Phenotypic expression of rubber tree clones in the northwestern region of São Paulo state. Bragantia. 2006; 65:389-398.

10. Gonçalves PS. Melhoramento genético da seringueira: métodos formais e moleculares. Informe Agropecuário, Belo Horizonte 2007; 28:95-104.

11. Iapar. Cartas climáticas do Estado do Paraná. Londrina: Iapar; 2000. CD-ROM.

12. Moreti D, Gonçalves PS, Gorgulho EP, Martins ALM, Bortoletto N. Estimativas de parâmetros genéticos e ganhos esperados com a seleção de caracteres juvenis em progênies de seringueira. Pesqu. agropec. bras. 1994; 29:1099-1109.

13. Ortolani AA. Agroclimatologia e o cultivo da seringueira. In: Anais do Simpósio sobre a cultura da seringueira no Estado de São Paulo. Campinas: Fundação Cargill; 1985. p.11-32.

14. Perecin D, Cargnelutti Filho A. Efeitos por comparações e por experimento em interações de experimentos fatoriais. Ciên. agrotec. 2008; 32:68-72.

15. Pereira JP, Leal AC, Doreto M, Castro AMG. Análise da Cadeia Produtiva da Borracha Natural do Paraná. In: Castro AMG, Lima AMV, Goedert WJ, Freitas Filho A, Vasconcelos JRP, editors. Cadeias Produtivas e Sistemas Naturais: Prospecção Tecnológica. Brasília: Embrapa; 1998. p.245-274.

16. Pereira, JP, Leal AC, Ramos ALM. Cultivo da Seringueira no Paraná. Londrina: Iapar; 2018. 176 p.

17. Pimentel-Gomes F, Garcia CH. Estatística aplicada a experimentos agronômicos e florestais: exposição com exemplos e orientações para uso de aplicativos. Piracicaba: Fealq; 2002. 309 p. 
Rubber clones $\mathrm{x}$ tapping systems in Paraná

18. Pushparajah E. Problems and potentials for establishing Hevea under difficult environmental conditions. The Planter 1980; 50:242-261.

19. Silva JQ, Souza MIT, Gonçalves PS, Pinotti RN. Sistemas de explotação de seringueira utilizados em clones asiáticos Prang Besar no Oeste paulista. Pesqu. agropec. bras. 2007a; 42:949-955.

20. Silva JQ, Souza MIT; Gonçalves PS, Pinotti RN, Aguiar ATE, Gouvêa LRL; Pinotti RN. Viabilidade econômica de diferentes sistemas de sangria em clones de seringueira. Pesqu. agropec. bras. 2007b; 42:349-356.

21. Silva JQ, Gonçalves PS; Scarpare Filho JA, Costa RB. Agronomical performance and profitability of exploitation systems in four rubber tree clones in São Paulo State. Bragantia 2010; 69:843-854.

22. Vasquez Cortez J. A evolução da cultura da seringueira no Estado de São Paulo, Brasil. In: Anais do $1^{\circ}$ Ciclo de palestras sobre heveicultura paulista; Barretos: Secretaria de Agricultura e Abastecimento/Associação Paulista de Produtores de Borracha; 1999. p.61-69. 